\title{
PENGEMBANGAN KOPER PINTAR BERBASIS ARDUINO
}

Development of smart suitcases-based arduino

\section{Anita Sari ${ }^{1}$, Novia Utami, S.T., MM. ${ }^{2}$, Selamet Samsugi., MT ${ }^{3}$, Sigit Doni Ramdan ${ }^{4}$}

\author{
${ }^{12}$ D3 Teknik Komputer, Universitas Teknokrat Indonesia \\ ${ }^{2,3}$ Fakultas Teknik dan Ilmu Komputer, Universitas Teknokrat Indonesia \\ ${ }^{4}$ S1 Teknik Elektro, Universitas Teknokrat Indonesia \\ Jl. ZA. Pagar Alam No.9 -11,Labuhan Ratu, Kec. Kedaton, \\ Kota Bandar Lampung, Lampung 35132. \\ anitasari2812@gmail.com, novia.utamiputri@gmail.com, s.samsugi@teknokrat.ac.id, sigitpapazola@gmail.com
}

\begin{abstract}
The safety factor becomes the main thing to watch out for as the number of cases of theft of suitcases in airplane passenger luggage is increasing. MCU nodes are used to help determine the position of the suitcase so that ownership of goods that are personal can be known for their existence status.The use of load cells is used as the main tool for improvisation in the development of smart luggage to become automatic. This sensor works as a weight sensor on a scale that will be used as a weight weigher from a suitcase that is currently filling clothes. The author found an idea to create an Arduino-Based Smart Suitcase. The tool uses an Arduino Uno microcontroller coupled with a $20 \mathrm{Kg}$ Load Cell weight sensor and GPS using MCU Node V.1.0 ESP8266 as a tracking of the existence of the suitcase position with other supporting components.
\end{abstract}

Keywords : Arduino Uno, Load cell weight sensor, Node MCU V.1.0 ESP8266, Smart Suitcase.

\begin{abstract}
Abstrak
Faktor keamanan menjadi hal utama yang harus diwaspadai banyaknya jumlah kasus pencurian koper di bagasi penumpang pesawat yang terus meningkat. Node MCU yang digunakan untuk membantu mengetahui keberadaan posisi koper sehingga kepemilikan barang yang bersifat pribadi dapat diketahui status keberadaanya. Penggunaan load cell digunakan sebagai alat utama untuk improvisasi pada pengembangan koper pintar agar menjadi otomatis. Sensor ini bekerja sebagai sensor berat pada sebuah timbangan yang akan digunakan sebagai penimbang berat dari koper yang sedang dalam pengisian pakaian. Penulis menemukan ide untuk membuat Koper Pintar Berbasis Arduino. Alat tersebut menggunakan mikrokontroler Arduino Uno dengan tambahan sensor berat Load Cell $20 \mathrm{Kg}$ dan GPS dengan menggunakan Node MCU V.1.0 ESP8266 sebagai pelacak keberadaan posisi koper dengan komponen pendukung lainnya .
\end{abstract}

Kata Kunci : Arduino Uno, Sensor berat load cell, Node MCU V.1.0 ESP8266, Koper Pintar.

\section{Pendahuluan}

Seiring dengan meningkatnya jumlah penumpang, faktor keamanan dan keselamatan penumpang terus diutamakan. Faktor keamanan di bandara menjadi hal utama yang harus diwaspadai mengingat banyaknya jumlah kasus pencurian tas koper di bagasi penumpang yang terus meningkat. Pada tanggal 9 Februari 2014, secara eklusif Cakrawala Telisik Antv menayangkan hasil investiagsi di bandara Soekarno-Hatta. Pada tahun 2013 Bandara Soekarno-Hatta mencatat terdapat 9 kasus pencurian tas koper di bagasi penumpang (Humas Polres Metro, 2013).

Untuk bagasi, pada setiap maskapai penerbangan memberikan kebijakan bagasi gratis dengan ketentuan bahwa berat setiap koper atau tas yang termasuk dalam jenis bagasi ini tidak melebihi $32 \mathrm{~kg}$.

Semakin majunya perkembangan teknologi berbagai inovasi tersebut maka diharapkan bisa dilakukan sistem keamanan. Salah satunya adalah dengan adanya sistem monitoring keberadaan posisi koper apabila koper tersebut jauh dari pemiliknya seperti lupa atau tertinggal disuatu tempat, maka koper dapat ditemukan dengan memanfaatkan teknologi GPS dan mengetahui berat koper secara otomatis menggunakan Load Cell. Dengan kenyamanan seperti itu para pemilik barang - barang pribadi yang bernilai mahal tidak perlu lagi merasa khawatir akan kehilangan koper saat sedang berpergian, kelalaian dari pemilik. Juga tidak harus takut kapasitas koper melebihi batas 
ukuran pada saat berpegian menggunakan pesawat karena dapat mengetahui berat koper secara otomatis. Dari permasalahan tersebut, maka penulis merancang suatu alat yang dapat membantu dan mengatasi masalah keamanan dan mengetahui kapasitas koper secara otomatis, maka penulis akan membuat laporan akhir yang berjudul "PENGEMBANGAN KOPER PINTAR BERBASIS ARDUINO" dengan harapan dapat membantu mengetahui keberadaan posisi koper sehingga kepemilikan suatu barang yang bersifat pribadi dapat diketahui status keberadaanya dan berat koper secara otomatis melalui maps pada android.

\section{Tinjauan Pustaka}

\subsection{Mikrokontroller Arduino Uno}

Arduino Uno merupakan sebuah perangkat mikro single-board yang didasarkan dari chip Atmel ATmega 328. Mikrokontroller ini memiliki 14 digital I/O (6 pin dapat digunakan sebagai output PWM) dan 6 analog input, $16 \mathrm{MHz}$ osilator kristal, koneksi USB, jack power, ICSP header, dan tombol reset. Mikrokontroller ini beroperasi pada tegangan 3,3 sampai 5V. Arduino Uno menggunakan IC Max232 yang digunakan sebagai USB-to-serial converter untuk komunikasi serial ke komputer melalui port USB. Kemudian flash memorinya dapat mencapai $32 \mathrm{~KB}$ dengan $0,5 \mathrm{~KB}$ diantaranya digunakan oleh bootloader, bentuk fisik dari Arduino Uno dapat dilihat pada gambar 2.1 sebagai berikut.

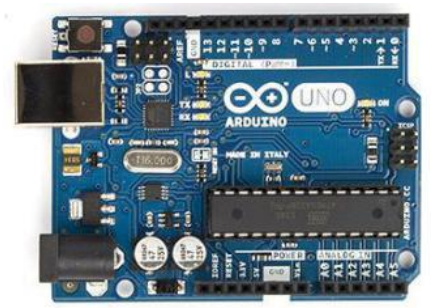

Gambar 2.1 Arduino Uno Board

\subsection{Load Cell}

Load cell adalah sebuah transducer yang dapat menghasilkan output secara proporsional dengan beban atau gaya yang diberikan. Load cell dapat memberikan pengukuran yang akurat dari gaya dan beban. Load cell digunakan untuk mengkonversikan regangan pada logam ke tahanan variabel sehingga menghasilkan sinyal listrik yang besarnya sebnading dengan berat yang diukur.

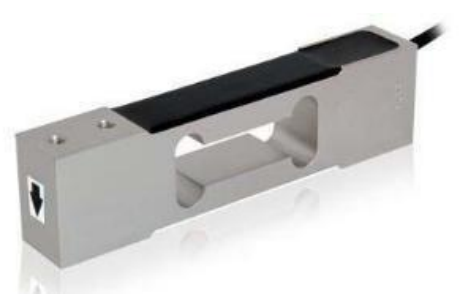

Gambar 2.2 Load Cell

\subsection{HX711}

HX711 merupakan sebuah modul timbangan dengan komponen yang terintegrasi dari "AVIA SEMICONDUCTOR" dengan kepresisian 24-bit ADC yang didesain untuk sensor timbangan digital dan aplikasi industri yang terkoneksi dengan sensor jembatan wheatstone.

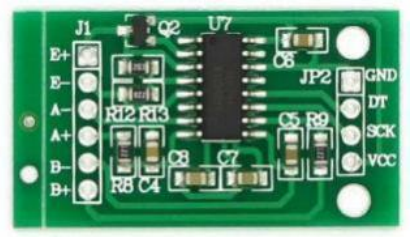

Gambar 2.3 HX711 Circuit

HX711 terdiri dari beberapa komponen yang saling terintegrasi antara lain yaitu kapasitor, resistor, transistor dan IC HX711 yang berfungsi sebagai regulator, penguat, osilator sehingga dapat mengeluarkan data output digital. Komponen dan rangkaian IC HX711. Dapat dilihat pada gambar 2.4 sebagai berikut.

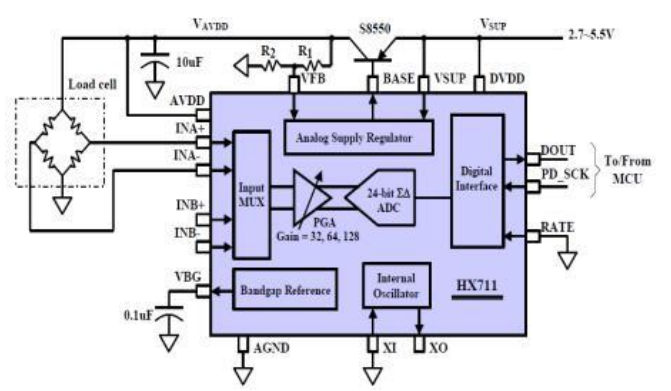

Gambar 2.4 HX711 Schematic

Perangkat ini bekerja berdasarkan input dari load cell yang terdiri dari strain gauge dengan bentuk jembatan wheatstone. Load cell yang digunakan dalam penelitian ini terdiri dari strain gauge dapat dilihat pada gambar dibawah ini.

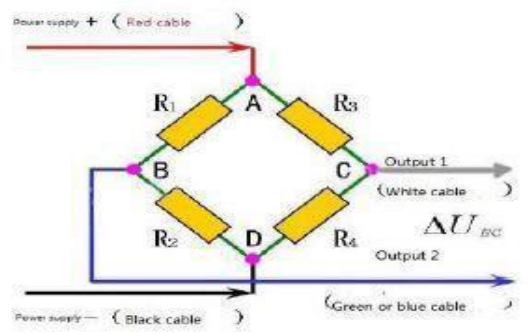

Gambar 2.5 Prinsip Penggunaan Strain gauge pada Load cell

Output strain gauge yang berbentuk jembatan wheatstone memiliki nilai sensitivitas yang tinggi dengan perubahan nilai output yang kecil. Dibutuhkan rangkaian penguat untuk membaca serta menguatkan output dari strain gauge tersebut.

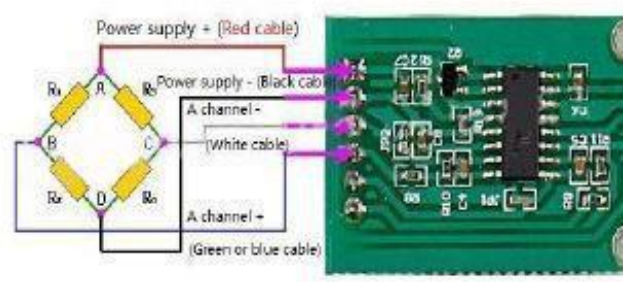

Gambar 2.6 Penggunaan HX711

\subsection{Buzzer}

Buzzer merupakan rangkain elektronika yang memiliki fungsi untuk mengubah getaran listrik menjadi suara. Prinsip kerja buzzer hampir sama dengan loudspeaker, yang terdiri dari kumparan yang terpasang 
pada diafragma dan kemudian kumparan tersebut dialiri arus sehingga menjadi electromagnet. Kumparan akan tertarik ke dalam atau keluar, sesuai dengan arah arus dan polaritas magnetnya, karena kumparan dipasang pada diafragma maka setiap gerakan kumparan akan menggerakkan diafragma secara bolak-balik sehingga membuat udara bergetar yang akan menghasilkan suara.

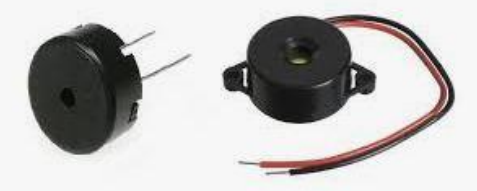

Gambar 2.7 Buzzer

\subsection{Node MCU V3}

Node MCU dilengkapi dengan micro usb port yang berfungsi untuk mentransfer progam sekaligus sebagai sumber tegangan dan di lengkapi dengan tombol reset dan flash. Node MCU menggunakan bahasa pemorgamanan Lua yang merupakan package dari esp8266. Selain dengan bahasa Lua dapat juga menggunakan Arduino IDE dengan melakukan sedikit perubahan board manager pada Arduino IDE. Jika menggunakan Arduino IDE maka firmware yang cocok digunakan ialah keluaran dari Ai-Thinker yang support AT Command. Tool loader Firmware yang dapat di gunakan adalah Firmware NodeMCU.

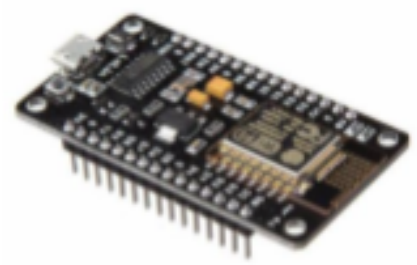

Gambar 2.8 Node MCU V1.0

\subsection{GPS Module}

GPS Module Merupakan jenis GPS yang memiliki sensitivitas tinggi dan daya rendah. GPS ini dirancang untuk berbagai aplikasi OEM dan didasarkan pada kemampuan pencarian tunggal GPS itu sendiri. Berikut ini adalah beberapa fitur yang terdapat dalam GPS Module:

1) Berdasarkan fitur kinerja tinggi dari chip set SiRFstarIII daya rendah tunggal

2) Modul kompak ukuran untuk integrasi yang mudah: 24x20x2.9 mm

$(0,94 \times 0,79 \times 0,11 \mathrm{di})$

3) Perakitan sepenuhnya otomatis: reflow solder perakitan siap

4) Kompatibel dengan perangkat lunak SiRF GSW3 3.2.2 v Hardware

5) Beberapa I / O pin disediakan untuk menyesuaikan aplikasi pengguna khusus

6) Dingin / Hangat / Hot Start Time: 42/35/1 detik. Langit terbuka dan lingkungan stasioner.

7) Perolehan kembali Waktu: 0,1 detik

8) RF Logam Shield untuk kinerja terbaik di lingkungan bising

9) Multi-path Mitigasi Hardware

10) TTL Port tingkat serial untuk GPS komunikasi antarmuka
11) Protokol: NMEA-0183/SiRF Binary (default NMEA)

12) Baud Rate: 4800, 9600, 19200, 38400 atau

57600 bps (default 4800)

13) Ideal untuk massa volume produksi tinggi

(Taping paket gulungan)

14) Biaya penghematan melalui penghapusan RF dan papan untuk

konektor digital

15) Fleksibel dan biaya desain hardware yang efektif untuk kebutuhan aplikasi yang berbeda

16) Aman SMD PCB pemasangan metode

\subsection{LCD 16x2}

LCD ialah media penampil yang menggunakan kristal cair sebagai layar utamanya. Fitur yang terdapat dalam LCD ini adalah:

- Terdiri atas 16 kolom dan 2 baris.

- Memiliki 192 karakter yang tersimpan.

- Terdapat karakter generator terprogram.

- Dapat menggunakan mode 4-bit dan 8-bit.

- dan Dilengkapi dengan sistem back light. Dapat dilihat pada gambar 2.10 sebagai berikut.

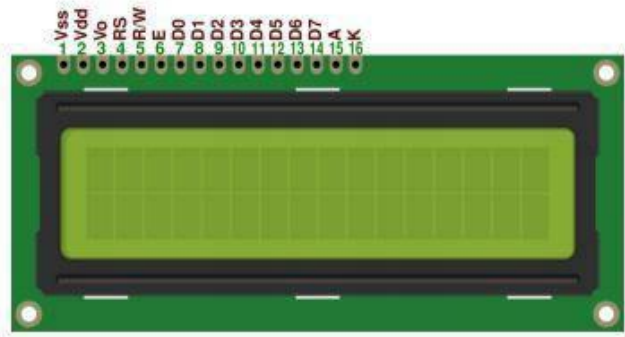

Gambar 2.10 LCD (Liquid Crystal Display) $16 \times 2$

\section{Metode}

\subsection{Pengumpulan Data}

Teknik pengumpulan data dilakukan dengan cara studi lapangan dan meminta data yang diperlukan serta wawancara langsung dengan pihak terkait.

\subsection{Analisa Kebutuhan}

Analisa kebutuhan ini berfungsi untuk mengetahui fitur apa saja yang diperlukan pada suatu sistem setelah datanya terkumpul.

\subsection{Perancangan Sistem}

Proses perancangan perlu dibuat agar mempermudah proses pembuatan alat, langkah sistemnya lebih terstuktur.

\subsection{Implementasi}

Setelah melaukan perancangan sistem maka selanjutnya adalah mengimplementasikan alat yang dirancang, dibuat sedimikian rupa hingga sensor-sensor dan komponen elektronika lainnya terpasang, setelah semua komponen elektronika terpasang tahap akhir adalah melakukan koding pada Arduino uno dengan software Arduino IDE.

\subsection{Uji Coba}

Uji coba pada sebuah alat penelitian sangat diperlukan untuk mengetahui apakah masih ada prosesproses yang diperlu diperbaiki.

\subsection{Sistematika Penulisan}


Penelitian merupakan suatu Karya Tulis yang dibuat oleh Mahasiswa yang telah melaksanakan penelitian dengan sistem penulisan yang telah ditentukan.

\begin{tabular}{|l|l|l|}
\hline \multirow{2}{*}{ SIM Card } & \multicolumn{2}{c|}{ Waktu Lokasi Ditemukan } \\
\cline { 2 - 3 } & Jaringan 3G & Jaringan 4G \\
\hline Telkomsel & 4 detik & 36 detik \\
\hline 3 & 28 detik & 83 detik \\
\hline M3 & 10 detik & 14 detik \\
\hline
\end{tabular}
mikrontroler dapat upload dengan penerimaan kode program dengan baik pada beberapa komponen yang digunakan untuk membuat alat. Rangkaian dibawah bisa dilihat bahwa arduino uno yang merupakan mikrokontroller untuk memproses segala aktivitas alat berfungsi sebagai otak dari alat, pada rangkaian tersebut terdapat LCD yang terkoneksi pada I2C dimana I2C meminimalisir penggunaan port pada arduino menjadi SDA dan SCL yang mana LCD akan menampilkan teks sesuai perintah arduino uno, lalu HX711 yang terhubung pada pin arduino sebagai modul menghitung berat dari beban yang ada pada Load Cell dan kemudian buzzer sebagai trigger saat berat melebihi maksimum yang telah ditetapkan di arduino, kemudian pada Node MCU yang mana disini dilakukan test koneksi apakah node MCU.

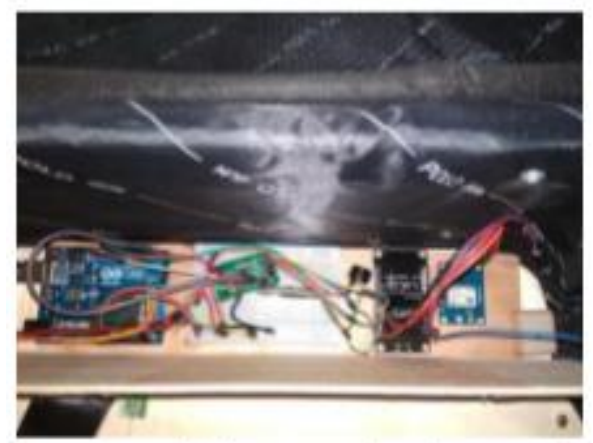

Gambar 4.1. Rangkaian Keseluruhan Mekanika Alat

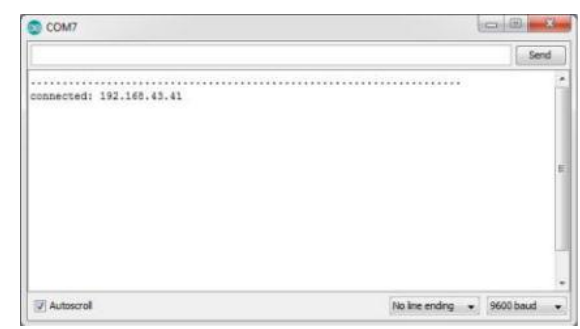

Gambar 4.2. Test Koneksi Pada Node MCU

\subsection{Pengujian GPS Berdasarkan Provider}

Pengujian ini dilakukan untuk menguji koneksi antara jaringan $4 \mathrm{G}$ dan $3 \mathrm{G}$ dengan menggunakan 3 macam sim card yang berbeda yaitu Telkomsel, 3, dan M3. Pengujian ini dilaksanakan di jalan Dokter Susilo, Gang Pusri 2, Teluk Betung Utara, Bandar Lampung. Berikut adalah tabel hasil pengujian dapat dilihat pada tabel 4.2 dan gambar 4.12 gambar grafik sim card sebagai berikut. Tabel 4.2 Pengujian Perbandingan 4G dan 3G Koneksi Sim Card sesuai Provider

\section{Grafik Presentase Waktu Lokasi Ditemukan}

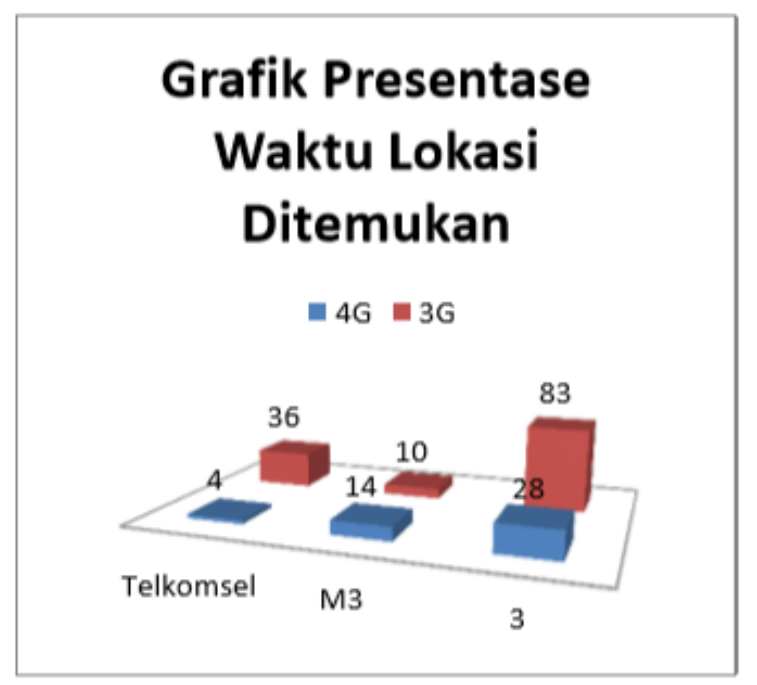

Gambar 4.3. Gambar grafik perbandingan SIM CARD sesuai provider

\section{Kesimpulan}

- Pengembangan koper Pintar yang telah dibuat oleh penulis dapat bekerja dengan baik dengan mampu mengetahui berat koper dan posisi koper dengan akurat, dapat di terapkan pada umum khususnya mengacu pada orang yang berpergian. Sehingga kepemilikan suatu barang yang bersifat pribadi dapat diketahui status keberadaanya dan berat koper secara otomatis.

- Sensor berat atau Load Chell berjalan baik dengan pengkalibrasian selisih keakurasian kurang dari $5 \%$ dengan pengukuran penimbangan beban posisi tegak lurus .

- GPS (Global Positioning System) pada node MCU memberikan posisi lokasi yang benar dengan akuratan +- 90-100\% dari posisi yang sebenarnya.

\section{Saran}

- Diharapkan pengembangan berikutnya dapat menggunakan keypad sebagai alat penginputan berat.

- Pengembangan mekanika perlu diperbaiki agar lebih baik seperti pemakaian bahan yang lebih kuat dari triplek agar dapat menahan berat lebih dari $30 \mathrm{~kg}$, dan penataan komponen juga diperbaiki agar terlihat rapi.

- Diharapkan pengembangan selanjutnya diberi alat pengaman untuk isi koper.

- Diharapkan Load Chell yang digunakan berat yang lebih dari $20 \mathrm{~kg}$.

- Diharapkan diberi buzzer pada node MCU untuk penelitian selanjutnya, agar pengguna 
lebih mudah mencari posisi koper pada jarak dekat.

\section{Journal Article}

\section{Daftar Pustaka}

[1] Andesita N.W., dan Agus W., 2018, Desain Koper Pintar Untuk Business Traveller, Jurnal Sains Dan Seni ITS Vol. 7, No. 1.

[2] Imam S., dan Wahyu S.P., 2015, Aplikasi Load Cell Untuk Otomatis Pada Depot Air Minum Isi Ulang, Jurnal Sains dan Teknologi ISSN: 2460173X Volume 1,Nomor 1.

[3] Muhammad Fajar W., 2017, Implementasi Wifi Modul Node MCU ESP8266 untuk Smart Home, Jurnal Teknik Komputer, Unikom, Komputika Volume 6, No.1.

[4] Muhammad S., dan Slamet W., Jurusan Sistem Komputer, Kaprodi SistemKomputer, Fakultas Ilmu Komputer, Universitas Narotama Surabaya.

[5] Rizkidiniah dkk, (2016), Perancangan dan Implementasi Prototype Sistem Gas (Global Positioning System) dan SMS Gateway Pada Pencarian Kendaraan Bermotor Berbasis Arduino Uno, Vol.2, No.2, pp. 87-92 ISSN : 2502-8928.

[6] Sisephaputra dkk, (2012), Sistem Pemantauan Keberadaan Jamaah Haji Menggunakan GPS Tracking Pada Smartphone Android (Studi Kasus : Kbih Al Ishlahiyyah Al Ghozaliyyah Tuban), Jurnal Sistem Informasi \& Komputer Akuntansi, 1(1), 1-8.

[7] Wahyudi, dkk, 2017, Perbandingan Nilai Ukur Sensor Load Cell pada Alat Penyotir Buah Otomatis terhadap Timbangan Manual, Jurnal Elkomika ISSN (e): 2459-9638, Vol. 5 No. 2 Halaman $207-220$. 